Immunology

\section{Paediatric mastocytosis}

\section{C Carter, D D Metcalfe}

\section{An unusual disease in infants and children}

M astocytosis in infants and children is an unusual disease characterised by an excess of mast cells in body tissues. The phenotypic expression of the disease is dependent on the pattern of localisation of the mast cells to specific organs and the release of mast cell mediators. The skin is the most common organ involved in children and may be the only manifestation of the disease. Mastocytosis can present from birth $^{1}$ to adulthood, with adult onset disease generally being more severe. The cutaneous form was recognised over 100 years ago, but the term mastocytosis, based on the offending cell, was initiated in 1936 by Sezary and Chauvillon. ${ }^{2}$

\section{AETIOLOGY AND PATHOGENESIS}

Mast cells are most abundant in connective tissues, with a predilection for peripheral nerves, and blood and lymphatic vessels. It is at these sites, under the influence of cytokines (interleukins
$3,4,5,6,9,10$, and 15$)^{3-9}$ and the principal mast cell growth factor, stem cell factor (SCF), that mast cells differentiate from a CD34+ pluripotent haematopoietic stem cell. ${ }^{10}$ This pluripotential cell expresses the receptor for SCF, KIT (CD117), but does not yet express the high affinity IgE receptor, Fc $\epsilon$ RI. ${ }^{11}$ SCF is present in a soluble and membrane bound form and is produced by fibroblasts, endothelial cells, and bone marrow stromal cells. This growth factor orchestrates the complete cycle of the mast cell from proliferation to differentiation. $^{12}$ Mastocytosis in some instances appears to be the clinical expression of disregulation of the production and function of mast cells caused by distinct activating somatic mutations in c-KIT (table 1 ). ${ }^{13}$ KIT is a type III transmembrane tyrosine kinase with an extracellular domain that binds mast cell growth factor, also known as SCF. Additionally, KIT is expressed by

Table 1 KIT mutations in children with sporadic disease

\begin{tabular}{ll}
\hline Mutation & Phenotype \\
\hline $\begin{array}{l}\text { Asp-816 } \rightarrow \text { Val } \\
\text { Asp-816 } \rightarrow \text { Phe }\end{array}$ & Uriticaria pigmentosa, with or without extensive disease \\
Asp-816 $\rightarrow$ Tyr & Urticaria pigmentosa, with or without systemic disease \\
Glu-839 $\rightarrow$ Lys & Urticaria pigmentosa \\
\hline
\end{tabular}

Table 2 Selected mast cell mediators and their effects

$\begin{array}{ll}\begin{array}{l}\text { Preformed secretory granule mediators } \\ \text { Histamine }\end{array} & \begin{array}{c}\text { Pruritis, increased vascular permeability, gastric hypersecretion, } \\ \text { bronchoconstriction } \\ \text { Local anticoagulation } \\ \text { Deparin } \\ \text { Tryptase, other proteases }\end{array} \\ \begin{array}{l}\text { Lipid derived } \\ \text { Sulphidopeptide leukotrienes }\end{array} & \begin{array}{l}\text { Increased vascular permeability, bronchoconstriction, } \\ \text { vasoconstriction, vasodilatation }\end{array} \\ \begin{array}{l}\text { Prostaglandin } \mathrm{D}_{2} \\ \text { Platelet activating factor }\end{array} & \begin{array}{l}\text { Increased vascular permeability, vasodilatation, } \\ \text { bronchoconstriction }\end{array} \\ \text { Cytokines } & \\ \text { TNF- } \alpha & \text { Activation of vascular endothelial cells, cachexia, fatigue } \\ \text { TGF- } \beta & \text { Fibrosis } \\ \text { IL-3 } & \text { Stimulation of haematopoiesis } \\ \text { IL-5 } & \text { Eosinophilia } \\ \text { IL-16 } & \text { Lymphocyte accumulation }\end{array}$

IL, interleukin; TGF, tumour growth factor; TNF, tumour necrosis factor.

and is essential for the development of melanocytes, haematopoietic stem cells, and the interstitial cell of Cajal. ${ }^{14}$

Other phenotypic expressions of KIT abnormalities are illustrated in the following situations: (1) autosomal dominant piebaldism in which a mutation decreasing KIT function results in a permanent localised absence of melanocytes and melanosomes; (2) c-KIT mutations have been found in neoplastic mast cell lines ${ }^{15}{ }^{16} ;(3)$ c-KIT somatic activating mutations have been found in human gastrointestinal stromal tumours ${ }^{17}{ }^{18}$; and (4) KIT protein expression is found in the neoplastic cells of approximately $63 \%$ of those with acute myelogenous leukaemia. ${ }^{19}{ }^{20}$ However, paediatric expression of these abnormalities is seen predominately in piebaldism and in paediatric onset mastocytosis with extracutaneous disease. There has been no identified c-KIT abnormality reported to date in familial mastocytosis. ${ }^{13}$

The sequelae of aberrant mast cell numbers and mediator release are linked to three categories of products: preformed mediators, lipid metabolites, and chemokines/cytokines. Symptoms of mastocytosis are to a great extent a direct result of spontaneous mediator release, or mediator release in response to immunological and non-immunological stimuli. Table 2 lists mast cell derived mediators and their contributions to disease manifestations. ${ }^{21}$

\section{CLINICAL PRESENTATIONS}

Approximately $65 \%$ of individuals with mastocytosis present with disease in childhood; $55 \%$ of these patients have manifestations of disease by the age of 2 years. ${ }^{1}$ The remaining 35\% of those that develop their disease after puberty are classified as adult onset. ${ }^{22}$ Although the occurrence of mastocytosis appears to be sporadic, there are reports of familial mastocytosis with dominance in several families. $^{23}$ Mastocytosis is classified based on prognosis and clinical presentation (table 3). ${ }^{24}$

\section{Cutaneous mastocytosis}

Children with cutaneous mastocytosis typically present with a spectrum of findings from solitary or multiple mastocytomas to urticaria pigmentosa (UP), or diffuse cutaneous mastocytosis (DCM). Blistering may occur in younger individuals, particularly with UP or DCM. ${ }^{25}$ Some children may exhibit features typical of more than one distinct category, each category of which is discussed below. Children with more extensive skin involvement are more likely to exhibit systemic symptoms. Telangiectasia muscularis eruptive persitans is a variant of UP, is associated with adult onset disease, and presents with diffuse telangiectasias. ${ }^{26}$ 


\begin{tabular}{l} 
Table 3 Mastocytosis \\
classification \\
\hline Cutaneous mastocytosis \\
1. Urticaria pigmentosa \\
2. Diffuse cutaneous mastocytosis \\
3. Mastocytoma of the skin \\
Systemic mastocytosis (without \\
AHNMD or leukaemic mast cell \\
disease) \\
1. Systemic indolent mastocytosis \\
2. Systemic smouldering mastocytosis \\
Systemic mastocytosis with an AHNMD \\
1. Myeloproliferative syndrome \\
2. Myelodysplastic syndrome \\
3. Acute myeloid leukaemia \\
4. Non-Hodgkin's lymphoma \\
Systemic aggressive mastocytosis \\
Mast cell leukaemia \\
Mast cell sarcoma \\
Extracutaneous mastocytoma \\
\hline Clasification adopted from WHO \\
classification. ${ }^{24}$. \\
AHNMD, associated haematological \\
non-mast cell disorder.
\end{tabular}

UP is the most frequent form of cutaneous mastocytosis. A subvariant consists of non-pigmented, plaque forming lesions that occur most often in infants. The lesions of UP appear as red-brown macules, papules, or plaques. These lesions are of varying size with the highest concentration usually on the trunk (fig 1). Darier's sign, present in the majority of patients with cutaneous mastocytosis, is the development of an urticarial wheal when a lesion is stroked and where the oedema is usually confined to the border of the lesion. In contrast, dermographism is the development of a wheal formation after stroking or scratching normal appearing skin. The triple response of Lewis is classically

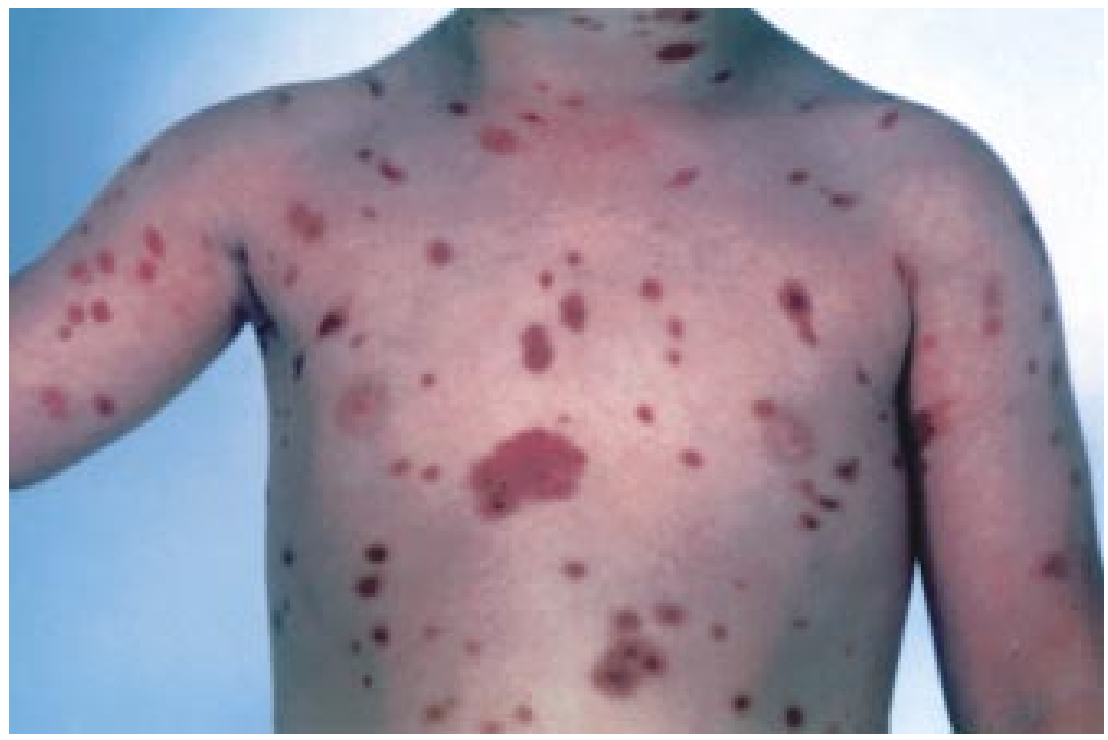

Figure 1 Child with urticaria pigmentosa. Both large and small pigmented lesions are visible.

described as the sequential development of a flush, a flare, and a wheal that may last for several hours. The most common associated symptom of UP is pruritis which varies in degree of intensity and chronicity. Flushing has been reported in association with bathing in hot or cold water, friction of the lesions, and exercise. ${ }^{27}$ Bullae and blistering may appear in the first few years of life and must be distinguished from other bullous diseases of childhood, such as pemphigoid (fig 2). Blister formation tends to be tense and may become haemorrhagic. Blistered areas usually heal without scar formation, unless the lesions become secondarily infected.$^{28}$ When the lesions of UP are not associated with systemic disease, there is a tendency for such lesions to fade during

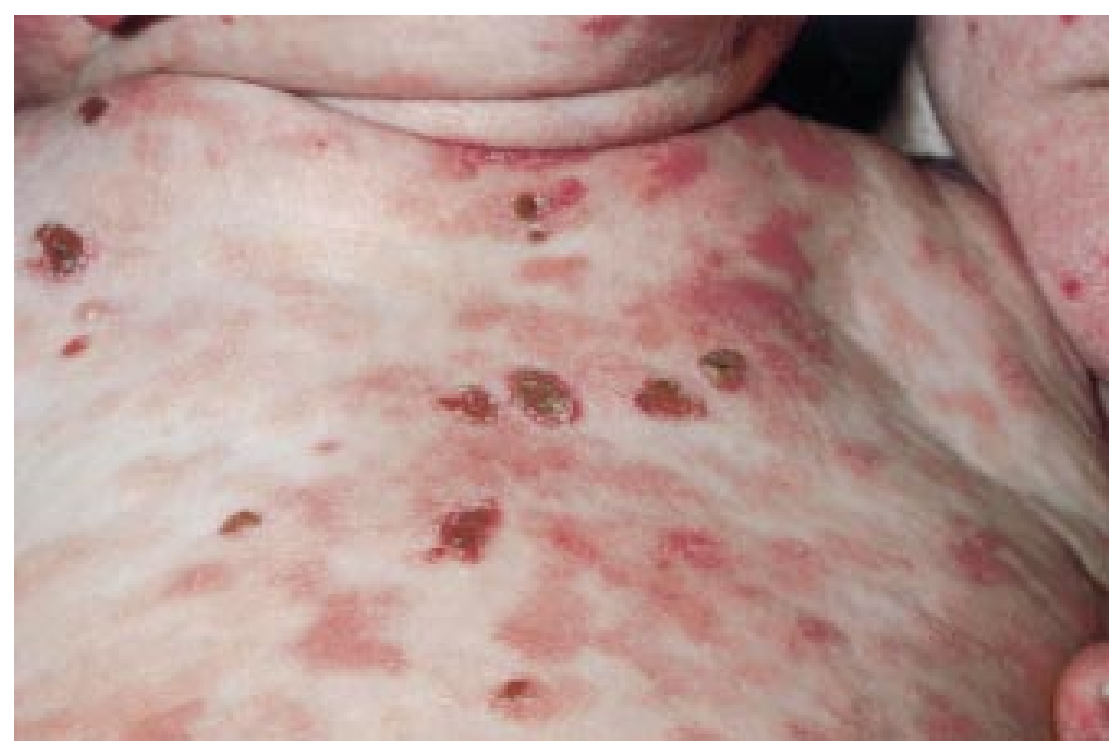

Figure 2 Bullous eruption in a child with mastocytosis. Note the generalised erythematous, crusted lesions and plaques, with a sterile bulla. adolescence. $^{29}$ Skin lesions of UP histologically show an accumulation of mast cells within the papillary dermis with variable extension throughout the reticular dermis and into the subcutaneous fat. Of interest, the incidence of atopic disease in patients with UP approximates that observed in the general population. ${ }^{30}$

Mastocytomas occur as brownish solitary or multiple nodules, which when traumatised may cause systemic symptoms, such as flushing and hypotension (fig 3). It is unusual for a child who presents with a solitary mastocytoma to develop further skin lesions more than two months after the presentation of the initial lesion. ${ }^{31}$ Histologically, sheets of mast cells without cytologic atypia fill the papillary and reticular dermis with variable extension into the subcutaneous tissues.

DCM is seen initially almost exclusively in infants, although it may persist into adult life..$^{25}$ The skin may be thickened with a peau d'orange appearance and/or a reddish-brown discoloration. ${ }^{1}$ Lesions characteristic of UP may also be present. Dermographism with the formation of haemorrhagic blisters is common. There is a distinct pattern of mast cell infiltration around blood vessels, in skin appendages, and throughout the dermis. Patients with DCM appear to be at increased risk for flushing, hypotension, shock, and death. ${ }^{29}$ Diarrhoea and other gastrointestinal manifestations are common. ${ }^{32}$

\section{Extracutaneous manifestations}

Patients with mastocytosis may have other associated findings based on the concentration of mast cells in other organ systems or systemic production of mediators. Thus, mastocytosis may affect the gastrointestinal tract, cardiovascular, 


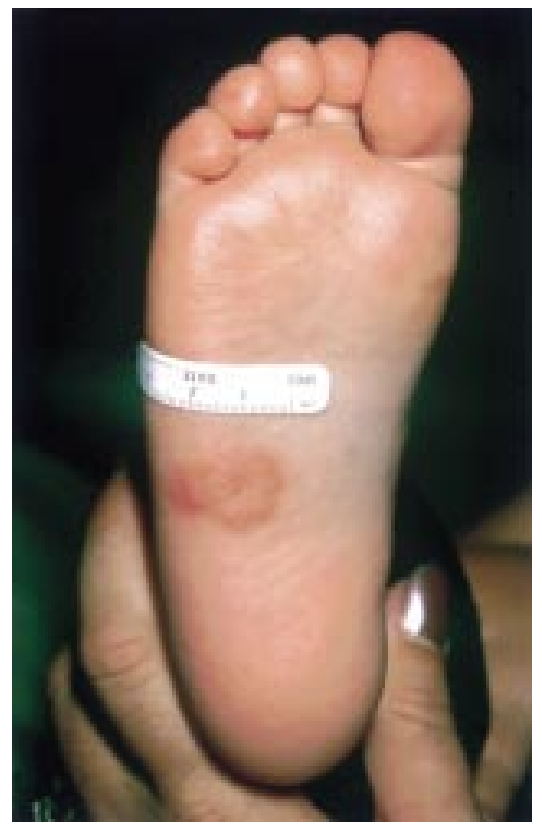

Figure 3 Mastocytoma on the sole of a 3 year old child. It usually occurs as a solitary nodule, but rarely on the palms and soles.

haematological, hepatic, and lymphoid tissues. Abnormal mast cell mediator release may also alter the function of the central nervous system and cardiovascular system. Patients with a nonphysiological increase in mast cells found in the bone marrow ${ }^{33}$ or in an organ system other than the skin are said to have systemic disease. ${ }^{34}$

Paediatric disease is less frequently associated with bone marrow pathology typical of systemic mastocytosis. Abnormalities in the bone marrow have, however, been shown in some children. These patients may have a substitution of valine for aspartate in codon 816

Table 4 Pharmacological agents and physical stimuli that may exacerbate mast cell mediator release in patients with mastocytosis

Immunological stimuli

Venoms (lgE mediated bee venom) Complement derived anaphylatoxins Biological peptides (substance P, somatostatin)

Polymers (dextran)

Non-immunological stimuli Physical stimuli (extreme temperature, friction, sunlight)

Drugs

Acetylsalicylic acid and related non-steroidal analgesics*

Thiamine

Ketorolac tromethamine

Alcohol

Narcotics (codeine, morphine)* Radiographic dyes (iodine containing)

*Appears to be a problem in less than $10 \%$ of patients.
(V816D). ${ }^{35}{ }^{36}$ A number of case reports have documented an association between UP and haematological malignancies. The most frequent association appears to be with acute myeloid leukaemia and acute lymphoblastic leukaemia. ${ }^{37}$ Systemic mast cell disease as defined by the presence of the classic bone marrow lesion associated with systemic mastocytosis was not observed in these cases. In one instance, the Philadelphia translocation $46, \quad \mathrm{XY}, t(9 ; 22)$ $(q 34 ; q 11) 38$ was observed.

In one survey of children with cutaneous mastocytosis, small perivascular and paratrabecular aggregates of mast cells, early myeloid cells, and eosinophils were observed in occasional individuals. ${ }^{39}$ Associated symptoms in such patients included pruritus (88\%), flushing $(65 \%)$, vesicles/bullae (53\%), abdominal pain $(41 \%)$, bone pain $(18 \%)$, and headache $(12 \%) .{ }^{40}$ The results were microscopically distinct from mast cell aggregates observed in the bone marrow of those with adult onset disease, although rare children with mastocytosis may have more severe bone marrow involvement. ${ }^{41-43} \mathrm{~A}$ bone scan reflects skeletal involvement and is sometimes used as an adjunct to other positive tests.

Haematological abnormalities are thus rare in children with mastocytosis and in patients who have mastocytosis otherwise limited to the skin. ${ }^{44}{ }^{45}$ Mild normochromic normocytic anaemia is the most common abnormality, although there have been reports of prolonged bleeding time caused by abnormal thrombin clotting times. Infants with DCM may be at greater risk for this complication. ${ }^{32}$ Hepatosplenomegaly is associated with systemic disease in the paediatric population.

Studies of various subpopulations of patients with mastocytosis have concluded that between $35 \%$ and $80 \%$ of adult patients with systemic mastocytosis have gastrointestinal involvement. ${ }^{33446}$ However, gastrointestinal involvement is much less common in children. ${ }^{47}$ Gastrointestinal bleeding is a potential complication with severe disease. It is believed to be provoked by high concentrations of circulating plasma histamine, which drives gastric hypersecretion. ${ }^{1}$ Abdominal cramping and diarrhoea have also been reported.

Patients with mastocytosis may react adversely to mast cell degranulating agents, such as narcotic analgesics ${ }^{48}{ }^{49}$ or polymixin B. ${ }^{50}$ Patients with mastocytosis may also be more sensitive to venoms of stinging insects. There are a number of activators of mast cell secretion, which work through immunological and nonimmunological mechanisms, which are summarised in table 4 . Children with cutaneous mastocytosis do not appear to have any unique behavioural patterns other than those which would be expected from the intense pruritus which may occur, from the side affects of antihistamines used to control itching and from problems in socialisation associated with the visible skin lesions. There is no clear psychopathology that exists in children with mastocytosis. ${ }^{51}$

\section{DIAGNOSIS}

Mastocytosis is diagnosed on the basis of history and clinical presentation, with confirmation of cutaneous involvement by biopsy. Stains such as toluidine blue or Giemsa, and the demonstration of mast cell tryptase by immunohistochemistry have been used to identify mast cells within cutaneous tissues. ${ }^{52}$ In some unusual circumstances degranulation of mast cells by a local anaesthetic may complicate the identification of mast cells.

Mast cell mediator concentrations may be increased in the plasma of patients with mastocytosis, but may also be increased in patients undergoing anaphylaxis. ${ }^{52}$ Plasma tryptase ${ }^{53}$ and histamine concentrations ${ }^{54}$ along with urine prostaglandin $\mathrm{D}_{2}^{55}$ and histamine metabolite concentrations ${ }^{56}$ are reflective of the increase in tissue mast cells and/or their activation.

Plasma histamine concentrations are known to be increased in the majority of the patients with paediatric onset mastocytosis. ${ }^{57}$ Another study showed high concentrations of N-methylhistamine in the urine of children with mastocytosis, with the highest concentrations suggestive of more severe and extensive disease, although there was some overlap with a normal control group. $^{58}$ A commercially available enzyme linked immunosorbent assay (ELISA) can determine amounts of plasma tryptase using a monoclonal antibody with a sensitivity of about 0.2 $\mathrm{ng} / \mathrm{ml}$. Median total plasma tryptase in healthy controls was $5.0 \mathrm{ng} / \mathrm{ml} .^{52}$ A total tryptase $\geqslant 20 \mathrm{ng} / \mathrm{ml}$ in association with a total tryptase to $\beta$ tryptase ratio of $\geqslant 20$ identifies patients more likely to have systemic mastocytosis. ${ }^{53}$

A bone marrow biopsy in those with paediatric onset cutaneous disease is not recommended unless there is evidence of systemic disease. Such evidence includes unexplained peripheral blood abnormalities, hepatosplenomegaly, and lymphadenopathy. ${ }^{57}$

\section{TREATMENT}

Therapy for mastocytosis is focused on providing symptomatic relief. Patients and parents should be counselled on avoidance of key triggers of mast cell degranulation such as extremes of temperature, certain medications, and Hymenoptera exposure. Fortunately, the symptoms of paediatric onset cutaneous disease are usually less severe than those observed in patients with adult onset 
mastocytosis. Pruritus, the most common symptom, is usually controllable to some degree with antihistamines and skin care in the majority of children. It does not usually reach the intensity that is associated with other pruritic diseases such as atopic dermatitis.

The treatment of choice is an antihistamine to block the $\mathrm{H}_{1}$ effects of histamine and control pruritis, flushing, and urticaria. Hydroxyzine, and more recently cetirizine or loratidine for less sedating properties, can be administered. In a double blind, placebo controlled, crossover trial, hydroxyzine was superior in children in reducing symptoms scores compared to ketitofen and had a similar side affect profile. ${ }^{40}$ The addition of an $\mathrm{H}_{2}$ antagonist may be useful to alleviate the symptoms associated with hypersecretion of gastric acid. Doxepin, with $\mathrm{H}_{1}$ and $\mathrm{H}_{2}$ properties, can be administered to children over 12 years. Orally administered disodium cromoglycate, although poorly absorbed, has been shown to relieve diarrhoea and abdominal cramping in some individuals. ${ }^{59}$ Disodium cromoglycate has also been reported to relieve musculoskeletal pain, headache, central nervous system complaints, and skin symptoms in some patients. ${ }^{60-64}$

Mastocytosis with bullous lesions in infancy sometimes presents with a shock like syndrome. ${ }^{65}$ As shown in one case study where the patient died of massive hypotension secondary to mast cell degranulation, ${ }^{65}$ it is prudent to administer adrenaline and other therapy as indicated including fluids, glucocorticoids, and $\mathrm{H}_{1}$ and $\mathrm{H}_{2}$ antihistamines. Bullae present in children less than 2 years of age can be managed in a similar fashion to scald injury with blistering. Care should be focused on prevention of infection and general skin health. Intravenous glucocorticoids have been used successfully to treat progressive severe bullae in infantile UP. ${ }^{31}$

Interferon $\alpha-2 b$ has been used to treat several adult patients with mastocytosis, but overall findings are inconclusive. ${ }^{66}$ Interferon $\alpha-2 b$ has shown some efficacy in controlling mast cell mediated symptoms, but appears less effective in decreasing the number and extent of UP and the extent of mast cell infiltration in the bone marrow. ${ }^{67-69}$ This drug has not been adequately studied in a paediatric population.

\section{PROGNOSIS}

The course of disease in paediatric onset cases is often benign in that there is no progression to systemic disease. In a review of 67 patients with UP, $83.7 \%$ developed lesions in the first year of life. In this same group the average duration of disease was 9.4 years. Approximately one third had improvement without clearing at an average of 6.1 years follow up. ${ }^{27}$ The skin lesions resolve in approximately half of the patients by adolescence. Notable improvement was expected in the remainder. ${ }^{31}$ Children whose mastocytosis persists into adulthood may experience a similar progression $\quad(15-30 \%)$ to systemic involvement. ${ }^{31}$

The prognosis for infants with cutaneous mastocytosis in part appears to depend on whether they exhibit bullae early in the neonatal period or if bullae are delayed relative to the appearance of their skin lesions. ${ }^{70}$ Children who manifest diffuse cutaneous mastocytosis prior to bullous eruptions appear to have a better chance at gradual improvement in their disease. Several reports of the occurrence of acute lymphocytic leukaemia in rapidly progressive and late onset paediatric onset mastocytosis suggest the possibility of a predilection for the development of a haematological malignancy in these patients. ${ }^{71}$

In summary, paediatric onset mastocytosis is an unusual disease with an often benign course. The disease in children is less likely to have a systemic component. Review of the literature suggests that those at potential risk for experiencing shock or sudden death include children with extensive bullous cutaneous involvement, those with symptoms of vasodilatation, flushing, and hypotension, and those with early onset of disease. ${ }^{65}$

Arch Dis Child 2002;86:315-319

\section{Authors' affiliations}

M C Carter, D D Metcalfe, NIAID/NIH,

Bethesda, MD, USA

Correspondence to: $\operatorname{Dr} M C$ Carter,

$\mathrm{NIH}$ /NIAID/LAD, Building 10, Room 11-C206

10 Center Dr. MSC 1881, Bethesda, MD

20892-1881,USA; mcarter@niaid.nih.gov

\section{REFERENCES}

Kettelhut BV, Metcalfe DD. Pediatric mastocytosis. Ann Allergy 1994;73:197207

2 Sezary ALCG, Chauvillon P. Dermographisme et mastocytose. Bull Soc Fr Dermatol Syph 1936:43:359-61

3 Kirshenbaum AS, Goff JP, Kessler SW, et al. Effect of IL-3 and stem cell factor on the appearance of human basophils and mast cells from CD34+ pluripotent progenitor cells. J Immunol 1992:148:772-7.

4 Dvorak AM, Seder RA, Paul WE, et al. Effects of interleukin-3 with or without the c-kit ligand, stem cell factor, on the survival and cytoplasmic granule formation of mouse basophils and mast cells in vitro. Am J Pathol 1994;144:160-70.

5 Rottem M, Kirshenbaum AS, Metcalfe DD. Early development of mast cells. Int Arch Allergy Appl Immunol 1991;94:104-9.

6 Yanagida $M$, Fukamachi $\mathrm{H}$, Ohgami $\mathrm{K}$, et al. Effects of T-helper 2-type cytokines, interleukin-3 (IL-3), IL-4, IL-5, and IL-6 on the survival of cultured human mast cells. Blood 1995;86:3705-14.

7 Godfraind C, Louahed J, Faulkner $\mathrm{H}$, et al. Intraepithelial infiltration by mast cells with both connective tissue-type and mucosal-type characteristics in gut, trachea, and kidneys of IL-9 transgenic mice. J Immunol 1998;160:3989-96

8 Thompson-Snipes L, Dhar V, Bond MW, et al. Interleukin 10: a novel stimulatory factor for mast cells and their progenitors. J Exp Med $1991 ; 173: 507-10$.

9 Tagaya Y, Burton JD, Miyamoto Y, Waldmann TA. Identification of a novel receptor/signal transduction pathway for IL-15/T in mast cells. Embo J 1996; 15:4928-39.

10 Kirshenbaum AS, Kessler SW, Goff JP, Metcalfe DD. Demonstration of the origin of human mast cells from CD34+ bone marrow progenitor cells. J Immunol

progenitor cells. J Imm

11 Rottem M, Okada T, Goff JP, Metcalfe DD. Mast cells cultured from the peripheral blood of normal donors and patients with mastocytosis originate from a CD34+/Fc epsilon RI-cell population. Blood 1994;84:2489-96.

12 Nilsson G, Metcalfe DD. Contemporary issues in mast cell biology. Allergy Asthma Proc 1996; 17:59-63.

13 Longley BJ Jr, Metcalfe DD, Tharp M, et al. Activating and dominant inactivating $\mathrm{c}-\mathrm{KIT}$ catalytic domain mutations in distinct clinical forms of human mastocytosis. Proc Natl Acad Sci U S A 1999:96:1609-14.

14 Huizinga JD, Thuneberg L, Kluppel $M$, et al. $\mathrm{W} / \mathrm{kit}$ gene required for interstitial cells of Cajal and for intestinal pacemaker activity. Nature 1995:373:347-9.

15 Furitsu T, Tsujimura T, Tono T, et al. Identification of mutations in the coding sequence of the proto-oncogene c-kit in a human mast cell leukemia cell line causing ligand-independent activation of c-kit product. J Clin Invest 1993;92:1736-44.

16 Kanakura Y, Furitsu T, Tsujimura T, et al. Activating mutations of the c-kit proto-oncogene in a human mast cell leukemia cell line. Leukemia 1994:8(suppl 1):S18-22.

17 Lux ML, Rubin BP, Biase TL, et al. KIT extracellular and kinase domain mutations in gastrointestinal stromal tumors. Am J Pathol 2000;156:791-5

18 Taniguchi $M$, Nishida T, Hirota S, et al. Effect of c-kit mutation on prognosis of gastrointestinal stromal tumors. Cancer Res 1999;59:4297-300

19 Kanakura $\mathrm{Y}$, Ikeda $\mathrm{H}$, Kitayama $\mathrm{H}$, et al. Expression, function and activation of the proto-oncogene c-kit product in human leukemia cells. Leuk Lymphoma 1993; 10:35-41

20 Wang C, Curtis JE, Geissler EN, et al. The expression of the proto-oncogene $\mathrm{C}$-kit in the blast cells of acute myeloblastic leukemia. Leukemia 1989;3:699-702.

21 Akin C, Metcalfe, DD. Mastocytosis. In: Leung DYMGM, ed. Allergic skin desease: a multidisciplinary approach. New York: Marcel Dekker, 2000:337-52.

22 Sondergaard JAHG. Mastocytosis in childhood. Heidelberg: Springer, 1987.

23 Shaw JM. Genetic aspects of urticaria pigmentosa. Arch Dermatol 1968;97:137-8.

24 Valent PHH, Li CY, Longley BJ, et al. World Health Organization classification of tumours, pathology and genetics of tumours of the haematopoietic and lymphoid tissues. Lyon: IARC Press, 2001.

25 Caplan RM. Urticaria pigmentosa and systemic mastocytosis. JAMA 1965; 194:1077-80

26 Gruchalla RS. Southwestern Internal Medicine Conference. Mastocytosis: developments during the past decade. Am $J$ Med Sci 1995;309:328-38.

27 Azana JM, Torrelo A, Mediero IG, Zambrano A. Urticaria pigmentosa: a review of 67 pediatric cases. Pediatr Dermatol 1994;11:102-6.

28 Longley J, Duffy TP, Kohn S. The mast cell and mast cell disease [published erratum appears in J Am Acad Dermatol 1995;33:52]. J Am Acad Dermatol $1995 ; 32: 545-64$. 
29 Soter NA. Mastocytosis and the skin. Hematol Oncol Clin North Am 2000;14:537-55, vi.

30 Muller U, Helbling A, Hunziker T, et al. Mastocytosis and atopy: a study of 33 patients with urticaria pigmentosa. Allergy 1990:45:597-603.

31 Caplan R. The natural course of urticaria pigmentosa. Arch Dermatol 1963;87:146-57.

32 Smith TF, Welch TR, Allen JB, Sondheimer $J M$. Cutaneous mastocytosis with bleeding: probable heparin effect. Cutis 1987;39:241-4.

33 Travis WD, Li CY, Bergstralh EJ, et al. Systemic mast cell disease. Analysis of 58 cases and literature review [published erratum appears in Medicine (Baltimore) 1990;69:34]. Medicine (Baltimore) 1988;67:345-68.

34 Horan RF, Austen KF. Systemic mastocytosis: retrospective review of a decade's clinical experience at the Brigham and Women's Hospital. J Invest Dermatol 1991;96:5S-14S

35 Nagata H, Okada T, Worobec AS, et al. c-kit mutation in a population of patients with mastocytosis. Int Arch Allergy Immunol 1997; 1 13:184-6.

36 Kirshenbaum AS, Kettelhut BV, Metcalfe DD Garriga MM. Mastocytosis in infants and children: recognition of patterns of skin disease. Allergy Proc 1989;10:17-21.

37 Longley BJ, Reguera M, Ma Y. Classes of c-KIT activating mutations: proposed mechanisms of action and implications for disease classification and therapy. Leuk Res 2001;25:571-6.

38 Lewis HM, Winter E, Darbyshire P, et al. Urticaria pigmentosa and acute lymphoblastic leukaemia. J R Soc Med 1995:88:530P_ $531 \mathrm{P}$.

39 Kettelhut BV, Parker RI, Travis WD, Metcalfe DD. Hematopathology of the bone marrow in pediatric cutaneous mastocytosis. A study of 17 patients. Am J Clin Pathol 1989:91:558-62

40 Kettelhut BV, Berkebile C, Bradley D, Metcalfe DD. A double-blind, placebo-controlled, crossover trial of ketotifen versus hydroxyzine in the treatment of pediatric mastocytosis. J Allergy Clin Immunol 1989;83:866-70.

41 Horny HP, Parwaresch MR, Lennert K. Bone marrow findings in systemic mastocytosis. Hum Pathol 1985; 16:808-14.

42 Ridell B, Olafsson JH, Roupe G, et al. The bone marrow in urticaria pigmentosa and systemic mastocytosis. Cell composition and mast cell density in relation to urinary excretion of tele-methylimidazoleacetic acid. Arch Dermatol 1986;122:422-7.

43 Webb TA, Li CY, Yam LT. Systemic mast cell disease: a clinical and hematopathologic study of 26 cases. Cancer 1982;49:927-38.

44 Cooper AJ, Winkelmann RK, Wiltsie JC. Hematologic malignancies occurring in patients with urticaria pigmentosa. J Am Acad Dermatol 1982:7:215-20.

45 Parker RI. Hematologic aspects of systemic mastocytosis. Hematol Oncol Clin North Am 2000; 14:557-68.

46 Parwaresch MR, Horny HP, Lennert K. Tissue mast cells in health and disease. Pathol Res Pract 1985;179:439-61.

47 Lucaya J, Perez-Candela V, Aso C, Calvo J. Mastocytosis with skeletal and gastrointestinal involvement in infancy. Two case reports and a review of the literature. Radiology 1979;131:363-6.

48 Fine J. Mastocytosis. Int J Dermatol 1980;19:117-23.

49 DiBascco RSDLV. Mastocyctosis and the mast cell. J Am Acad Dermatol 1982;7:709-22.

50 Sutter MC BG, Birt AR. Histamine liberation by codiene and polymyxin $B$ in urticaria pigmentosa. Arch Dermatol 1962:86:217-21.

51 McFarlin KE, Kruesi M, Metcalfe DD. A preliminary assessment of behavioral problems in children with mastocytosis. Int J Psychiatry Med 1991;21:281-9.

52 Akin C Schwartz LB, Kitoh T, et al. Soluble stem cell factor receptor (CD 1 17) and IL-2 receptor alpha chain (CD25) levels in the plasma of patients with mastocytosis: relationships to disease severity and bone marrow pathology. Blood 2000;96:1267-73.

53 Schwartz LB, Sakai K, Bradford TR, et al. The alpha form of human tryptase is the predominant type present in blood at baseline in normal subjects and is elevated in those with systemic mastocytosis. J Clin Invest 1995;96:2702-10

54 Friedman BS, Steinberg SC, Meggs WJ, et al. Analysis of plasma histamine levels in patients with mast cell disorders. Am J Med 1989;87:649-54

55 Roberts LJD, Sweetman BJ, Lewis RA, et al. Increased production of prostaglandin D2 in patients with systemic mastocytosis. $N$ Engl J Med 1980;303:1400-4.

56 Granerus G, Roupe G. Increased urinary methylimidazoleacetic acid (MelmAA) as an indicator of systemic mastocytosis. Agents Actions 1982;12:29-31.

57 Kettelhut BV, Metcalfe DD. Plasma histamine concentrations in evaluation of pediatric mastocytosis. J Pediatr 1987:111:419-21.

58 Van Gysel D, Oranje AP, Vermeiden I, et al. Value of urinary $\mathrm{N}$-methylhistamine measurements in childhood mastocytosis. J Am Acad Dermatol 1996;35:556-8.

59 Horan RF, Sheffer AL, Austen KF. Cromolyn sodium in the management of systemic mastocytosis. J Allergy Clin Immunol 1990;85:852-5.

60 Alexander RR. Disodium cromoglycate in the treatment of systemic mastocytosis involving only bone. Acta Haematol 1985;74:108-10.

61 Businco L, Cantani A, Businco E, Pepys J. Systemic mastocytosis in a 5-year-old child: successful treatment with disodium cromoglycate. Clin Allergy 1984;14:147-52.

62 Czarnetzki BM, Behrendt H. Urticaria pigmentosa: clinical picture and response to oral disodium cromoglycate. $\mathrm{Br} J$ Dermatol 1981;105:563-7.

63 Welch EA, Alper JC, Bogaars H, Farrell DS Treatment of bullous mastocytosis with disodium cromoglycate. J Am Acad Dermatol 1983;9:349-53

64 Zachariae H, Herlin T, Larsen PO. Oral disodium cromoglycate in mastocytosis. Acta Derm Venereol 1981:61:272-3.

65 Murphy M, Walsh D, Drumm B, Watson R. Bullous mastocytosis: a fatal outcome. Pediatr Dermatol 1999;16:452-5.

66 Worobec AS, Kirshenbaum AS, Schwartz LB, Metcalfe DD. Treatment of three patients with systemic mastocytosis with interferon alpha-2b. Leuk Lymphoma 1996;22:501-8.

67 Granerus G, Lonnqvist B, Roupe G. Histamine metabolism in mastocytosis patients treated with interferon alpha-2b. Inflamm Res 1996;45(suppl 1):S41-3.

68 Czarnetzki BM, Algermissen B, Jeep S, et al. Interferon treatment of patients with chronic urticaria and mastocytosis. J Am Acad Dermatol 1994;30:500-1

69 Kolde G, Sunderkotter C, Luger TA. Treatment of urticaria pigmentosa using interferon alpha. Br J Dermatol 1995; 133:91-4.

70 Orkin M, Good RA, Clawson CC, et al. Bullous mastocytosis. Arch Dermatol 1970;101:547-64

71 Fromer JL, Jaffe N. Urticaria pigmentosa and acute lymphoblastic leukemia. Arch Dermatol 1973:107:283-4. 